\title{
子宮腺筋症に対する子宮鏡下子宮内膜削除術の有用性の検討
}

東京都保健医療公社 大久保病院 婦人科

吉田梨恵、高田淳子、羽田野景子、薄井千絵

\section{Usefulness of hysteroscopic endometrial ablation for adenomyosis}

\author{
Rie Yoshida, Junko Takada, Keiko Hatano, Chie Usui
}

Department of Gynecology, Tokyo Metropolitan Health and Hospitals Corporation, Ohkubo Hospital

\begin{abstract}
Objective: The aim of this study was to evaluate the usefulness of hysteroscopic endometrial ablation for adenomyosis with hypermenorrhea.

Design: Retrospective analysis

Setting: Tokyo Metropolitan Health and Hospitals Corporation, Ohkubo Hospital, Japan

Method(s): From January 2011 to December 2017, 14 women with hypermenorrhea underwent hysteroscopic endometrial ablation for adenomyosis. Surgical outcomes and complications were evaluated. In our method, the endometrium and a part of the myometrium lining the uterus (approximately $5 \mathrm{~mm}$ in depth) were resected.

Result(s): All patients had decreased bleeding. Four patients had amenorrhea (28.6\%) and 10 patients had menorrhea (71.4\%). The recurrence of hypermenorrhea and major complications were not reported. Three patients with dysmenorrhea needed additional treatments but were relieved by hormonal therapy and were able to avoid hysterectomy.
\end{abstract}

Conclusion(s): Hysteroscopic endometrial ablation for adenomyosis is an effective and safe procedure that can reduce the hysterectomy rate.

Key words: hysteroscopy, endometrial ablation, adenomyosis

\section{緒言}

子宮腺筋症は良性疾患ではあるが過多月経や貧 血、月経困難症によるQOLの低下を示すことが あり、対応に苦慮することも多い。当院では治療 として従来のホルモン療法を第一選択として施行 しているが、ホルモン療法が無効であった症例に 対しては過多月経の改善目的に子宮鏡下子宮内膜 削除術を施行している。これは子宮鏡下に切断ル ープを使用して子宮内膜と筋層の一部を全周性に 切除、燒灼する方法であり、子宮内膜アブレーシ ヨンの第一世代に相当する。単なる子宮内膜の焼 灼だけではなく、筋層の一部まで切除することで より確実な内膜の削除と月経量の低下を目的とし ている。現在まで良好な経過を得ており、今回は この術式の有用性について当院で施行した経験を
もとに検討し報告する。

\section{対象および方法}

2011年 1 月から 2017 年12月までに子宮鏡下子宮 内膜削除術を施行した14例を対象とし、後方視的 に検討を行った。

手術適応は過多月経をともなう子宮腺筋症症例 で、妊孕性温存希望のない事、子宮摘出の希望が ない事、保存的治療に抵抗性を示す事、低侵襲の 加療を希望している事などを条件とした。手術前 に子宮頚部細胞診、子宮内膜細胞診等で悪性疾患 の除外を行うほか、子宮鏡検査で子宮内腔を観察 し子宮内腔の拡張や不規則な血管像、腺開口、異 型血管、突出病変の有無を観察した。なお子宮内 膜の菲薄化を期待し、術前に全例でGnRHアゴニ ストを 1 〜 回投与した。 
当院では当手術は 2 泊 3 日で行っており、入院 当日に経管拡張を行い、翌日に全身麻酔下で手術 を施行している。子宮鏡はOlympus社、KarlStorz社のモノポーラヒステロレゼクトスコープ $26 \mathrm{Fr}$ 使用し、灌流液は 3 \% D-ソルビトールを 用いた。高周波電流の出力設定は切開時は60W、 凝固時は $60 \mathrm{~W}$ とした。子宮内腔に子宮筋腫や子宮 内膜ポリープ等の突出病変がある場合はまず病変 の切除を行い、その後に90度のループ電極を用い て子宮底部の手前から子宮峡部までの内膜を子宮 筋層とともに全周性に切除した（図 1 )。子宮穿 孔の予防のため、切除の深さは 5 ミリ程度を目安 とした。左右卵管角と子宮底部は子宮穿孔のリス クが高いため、ローラー電極もしくはボール電極 を用いて焼灼、凝固した。なお切除面からの出血 は随時凝固止血を行うように留意した。術後は病 状経過に加え、ヒステロファイバースコープにて 定期観察し子宮内膜の再生や子宮内腔の癒着の有 無等を確認した。

統計学的解析はt検定、Fisherの正確確率検定

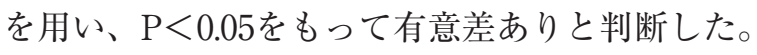

\section{結＼cjkstart果}

患者背景、手術結果を表 1 、手術成績を表 2 に 示す。過多月経は全例で改善し、術後 3 か月目の 血中Hb濃度は有意に上昇を認めた。術後から現 在まで35〜85か月観察しており、現在も全例で過 多月経の再発はみられていない（表 3 )。

ヒステロファイバースコープでの観察において は、術前は子宮腺筋症特有の子宮内胿の拡張を認 めるが術後の内腔は灰白色を呈し、疲痕化が認め られた（図 1 )。その後も子宮内膜の再生や子宮 内腔の癒着の有無等を定期観察したところ、術後 3〜 5か月ほどで内膜焼灼のみ施行していた卵管 口付近や子宮底部の内膜の一部が再生し、月経が 再開していた。しかし月経量は術前に比較し減少 を認め、さらに術後から現在まで無月経の症例も 4 例みられた。なお、子宮内腔の一部で膜状の癒 着を認める症例はあったが、広範囲なものや強固 な結合織を形成するような症例は認めなかった。

一方、術後追加治療を要したものが 3 例みられ た（表 4)。いずれも過多月経は改善するも術前

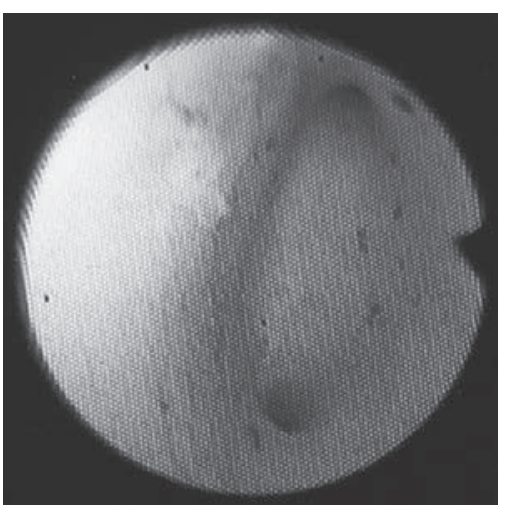

a術前：子宮腺筋症の特徵である子宮内腔の 拡張が認められる.

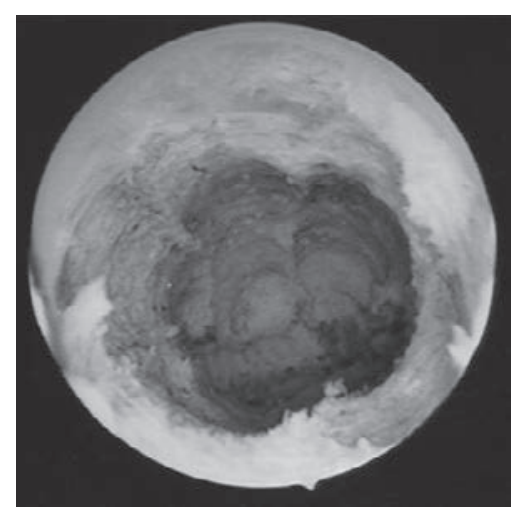

$d$ 手術終了時

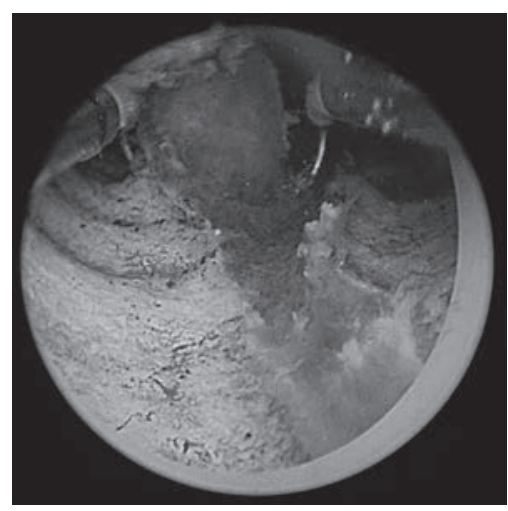

b手術所見

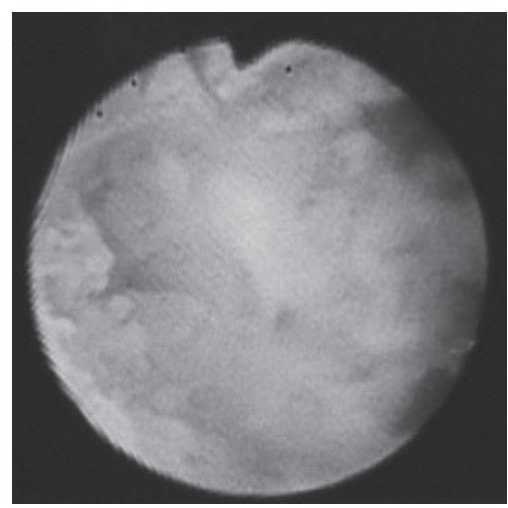

$\mathrm{e}$ 術後3か月目: 卵管口周囲のみ内膜再生が 認められる.

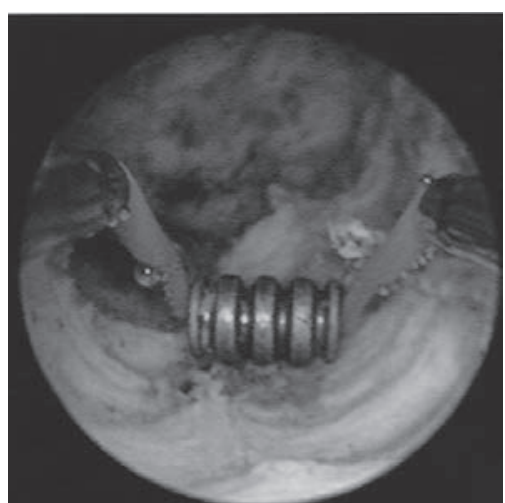

C手術所見

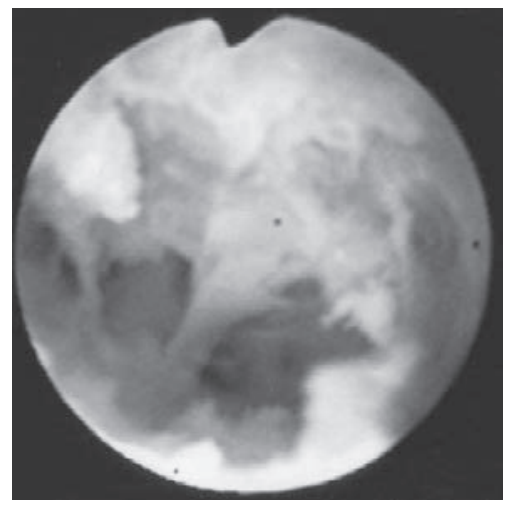

f術後3か月目 : 子宮内腔の一部に癒着が認め られる.

図 1 子宮内腔所見 
表 1 患者背景・手術結果

\begin{tabular}{cc}
\hline 症例数 & 14例 \\
\hline 年齢 $($ 歳 $)$ & $46 \pm 3.1$ \\
BMI $\left(\mathrm{kg} / \mathrm{m}^{2}\right)$ & $20.7 \pm 21.9$ \\
手術時間(分) & $16.1 \pm 8.6$ \\
灌流液量 $(\mathrm{ml})$ & $5257.1 \pm 3032.8$ \\
& \\
灌流液INOUTバランス $(\mathrm{ml})$ & +435.7 \\
合併症 & 低 \\
& $(7.1 \%)$ \\
\hline
\end{tabular}

* BMI:Body Mass Index ～*データは平均士SD もしくは症例数(\%)を示す.

表 2 手術成績

\begin{tabular}{cccc}
\hline & 術前 & 術後3か月目 & p-value \\
\hline 血中Hb濃度 $(\mathrm{g} / \mathrm{dl})$ & $9.9 \pm 2.5$ & $13 \pm 6.8$ & $\mathrm{P}<0.05$ \\
過多月経 & 14例 $(100 \%)$ & 0 & \\
月経痛 & 14例 $(100 \%)$ & 3例 $(21.4 \%)$ & $\mathrm{P}<0.05$ \\
& & & \\
\hline & $*$ *゙ータは平均士SD もしくは症例数 $(\%)$ を示す.
\end{tabular}

表 3 術後経過

\begin{tabular}{cc}
\hline 症例数 & 14例 \\
\hline 過多月経改善 & 14例 $(100 \%)$ \\
月経再開平均 & 3 か月 \\
月経痛残存 & (無月経症例 4例) \\
追加治療 & 3 例 $(21.4 \%)$ \\
& 3 例 $(21.4 \%)$ \\
\hline
\end{tabular}

*データは症例数 $(\%)$ を示す

からの月経痛症状はかわらず残存したため、ホル モン治療を施行している。詳細には、1例目は術 後無月経となるも月経周期で月経時期に相当する 期間に下腹部痛があり、術後よりジエノゲストの 内服を継続している。2例目は術後 3 か月目に月 経が再開するとともに術前と同様の月経痛が再燃 したため、GnRHアゴニスト投与後にジエノゲス 卜内服を継続している。3 例目も術後 5 か月目で 月経が再開するとともに月経痛が再燃し、LNGIUS挿入となった。現在は当 3 例は無月経状態が
継続しており、疼痛のコントロールは良好である。 また、術中合併症として低Na血症（血清 $\mathrm{Na}$ 值 $135 \mathrm{mmol} / \mathrm{l}$ ) を 1 例認めたが、脳浮腫や肺水腫等の 重篤な兆候は認めず、自覚症状もなく翌日退院と なった。感染、子宮穿孔を認めた症例はなかった。

なお、術後の病理組織検查では筋層内に入り込 むように内膜組織がみられ、子宮腺筋症として矛 盾のない所見が得られた（図 2 )。悪性疾患を疑 う所見は認めなかった。 
表 4 追加治療例の患者背景・経過

\begin{tabular}{|c|c|c|c|c|c|c|}
\hline & 年齢 & $\begin{array}{l}\text { 合併症 } \\
\text { 既往 }\end{array}$ & $\begin{array}{c}\text { 術前 } \\
\text { 月経痛 }\end{array}$ & $\begin{array}{c}\text { 術後 } \\
\text { 月経再開 }\end{array}$ & 術後 & 追加治療 \\
\hline 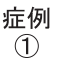 & 46 & なし & + & 無月経 & $\begin{array}{c}\text { 毎月の } \\
\text { 下腹部痛 }\end{array}$ & $\begin{array}{l}\text { ジェノゲスト } \\
\text { 内服の継続 }\end{array}$ \\
\hline $\begin{array}{l}\text { 症例 } \\
\text { (2) }\end{array}$ & 44 & $\begin{array}{c}\text { 右内膜症性 } \\
\text { 裳胞合併 }\end{array}$ & + & $\begin{array}{l}\text { 術後 } \\
\text { 3か月 }\end{array}$ & $\begin{array}{c}\text { 月経再開後 } \\
\text { 下腹部痛 }\end{array}$ & $\begin{array}{c}\text { 月経再開後、 } \\
\text { GnRH5回投与 } \\
\rightarrow \text { 術後5か月 } \\
\text { より無月経 } \\
\rightarrow \text { ジエノゲスト } \\
\text { 内服 }\end{array}$ \\
\hline 症例 & 46 & $\begin{array}{c}\text { 腹腔鏡下卯巣囊腫 } \\
\text { 摘出術 } \\
\text { (内膜症性囊胞） } \\
\text { 既往 }\end{array}$ & + & $\begin{array}{c}\text { 術後 } \\
5 \text { か月 }\end{array}$ & $\begin{array}{c}\text { 月経再開後 } \\
\text { 下腹部痛 }\end{array}$ & $\begin{array}{l}\text { 月経再開後、 } \\
\text { LNG-IUS㨉入 }\end{array}$ \\
\hline
\end{tabular}

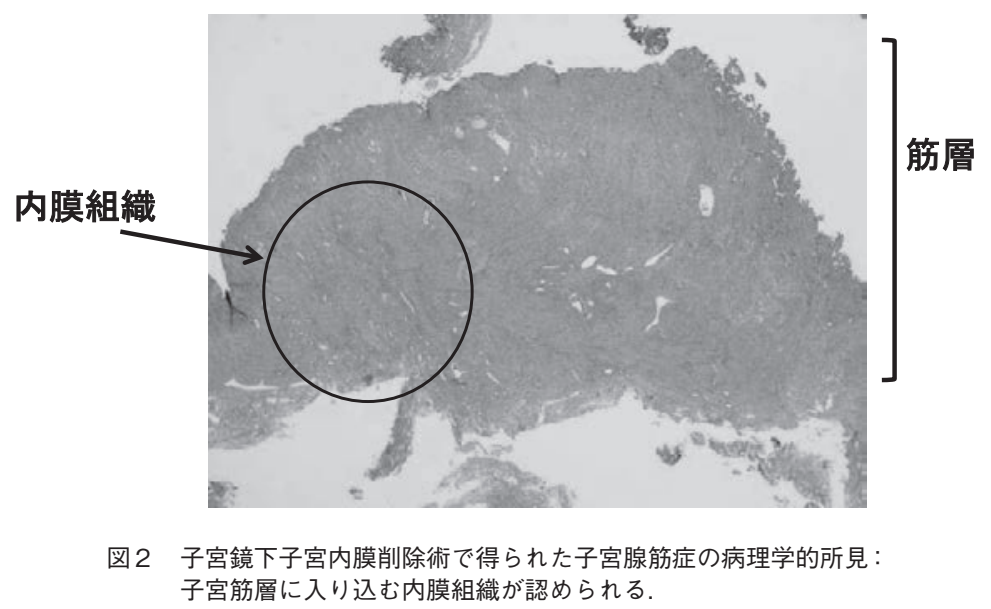

\section{考察}

子宮内膜アブレーションは過多月経の治療とし て高い治療効果と満足度が得られるとされてお り、これまで様々な方法が報告されてきた。うち、 第一世代の子宮鏡下子宮内膜燒灼術は病理組織検 査が可能である点や確実に内膜を破壊できる点で メリットがある方法である。病理検查で子宮内膜 増殖症と診断される報告もあり ${ }^{1)}$ 、子宮悪性疾患 の早期発見の機会となりうる点でも有用性がある といえる。

当院では現在までに34例施行しているが、全例 で過多月経は改善を認め、術後の血中Hb濃度も 上昇がみられている。今回、ホルモン治療に抵抗 性であった子宮腺筋症症例に损いても14例全てで 過多月経の改善を認め、さらに術後無月経のまま で経過している症例も確認できた。子宮内腔の変 化に打いても内膜の切除による子宮内腔の白色痏
痕化や、その後の一部の内膜再生による月経再開 と月経量の減少を示唆する所見が得られている。 なお、内子宮口焼灼後の子宮口癒着を防ぐ目的で、 切除範囲は子宮底部の手前から子宮峡部までとし ている。当院では幸い子宮内腔に強固な癒着を形 成するような症例は認めていないが、術後も 3 〜 6 か月毎でヒステロファイバースコープを用いた 定期観察をし膜状癒着は随時切除を行っている。

子宮内膜アブレーション後に子宮摘出となるリ スクは10 $22 \%^{2-4)}$ と報告されており、さらに子 宮摘出になった症例の $80 \%$ が術後 3 年以内 ${ }^{3)}$ であ ることから、術後も症状再燃に留意する必要があ るとされる。今回施行した子宮鏡下子宮内膜削除 術においては、当院では現在まで過多月経再燃や 子宮摘出となった症例はない。より確実な子宮内 膜の削除が内膜再生を抑制し、過多月経再発の抑 制に寄与している可能性が示唆された。さらに筋 層の一部を切除するため、得られた病理組織検体 
から子宮腺筋症の病理学的診断と悪性疾患の鑑別 が可能である点においても有用であると考える。

一方、子宮腺筋症では月経困難症を伴うため、 アブレーションによる月経量改善後も月経痛のコ ントロールを要することも多いとされる。術後に 子宮摘出となる例が散見され、Shavellらは、子 宮内膜アブレーション後に子宮摘出となった症例 の $44.4 \%$ に腺筋症がみられたとしている ${ }^{3)}$ 。その ため子宮腺筋症を子宮内膜アブレーションの適応 としていない報告もある ${ }^{5}$ 。当院でも子宮内膜ポ リープや子宮筋腫の過多月経に当術式を施行した 症例では現在まで追加治療を要したものはない が、子宮腺筋症症例では 3 例が追加治療となって いる。これらは子宮摘出は回避できているものの、 月経痛症状によりホルモン治療を要した。また、 これらは術前から月経痛症状が強く、子宮内膜症 の存在も示唆されていた。子宮腺筋症においては 術後も月経痛の残存を考慮し、状況に応じホルモ ン治療を追加する必要があるといえる。しかし子 宮内膜削除術を行うことで、術前はホルモン療法 を行っていても不正出血等の副作用に難渋した症 例や充分な治療効果を得られなかった症例でも、 まずは過多月経・不正出血の改善が期待できるこ とが示された。貧血や患者のQOL改善により以 後もホルモン療法の継続が可能となるため、子宮 摘出を回避できる可能性はあると思われた。

合併症に関しては、低Na血症を 1 例認めた。 原因として子宮内腔を全周性に処置するため手術 時間がかかりやすい点や、筋層の一部の切除によ り血管が露出され、灌流液を吸収しやすい点が考 えられる。なお水中毒は灌流液INOUTバランス でINが1000ml以上、手術時間90分でリスクが高

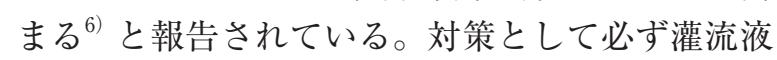
INOUTバランスの測定を行い、手術時間が30分 以上抏よび灌流液INOUTバランスでINが1000ml 以上の症例においては採血による電解質の確認を 行っているが、状況により術中も随時確認を行う ことが必要と思われた。さらに今後の当手術にお いては、時間あたりの灌流液流入を減らす工夫が 必要と考えらえた。現在ではバイポーラ機器を使 用するようにしているが、切除筋層の深さの再検 討や止血の徹底など今後も術式の検討をしていき たいと思う。

\section{結 論}

子宮鏡下子宮内膜削除術は、より確実な内膜削 除をおこなうことで過多月経の改善に寄与する治
療であると考える。子宮腺筋症症例においても症 状再燃のリスクも少なく、病理学的診断も可能で ある点でメリットがあると思われる。術後も月経 痛の残存に考慮する必要があるものの、術後ホル モン治療を追加することで子宮全摘術を回避で き、低侵襲に加療できる可能性があるといえる。

本論文の要旨は第 58 回日本産科婦人科内視鏡学 会において発表した。すべての著者は開示すべき 利益相反はない。

\section{文 献}

1）荻原聖子. 小堀宏之. 過多月経に対するレゼクトスコ ープを用いた子宮内膜燒灼術. 関東産婦誌 $2016 ; 53$ : 83-89

2) Longinotti MK, Jacobson GF, Hung YY et al. Probability of hysterectomy after endometrial ablation. Obstet Gynecol 2008; 112: 1214-1220

3 ) Shavell VI, Diamond MP, Senter JP et al. Hysterectomy subsequent to endometrial ablation.J Minim Invasive gynecol 2012; 19 (4): 459-464

4) Smithling KR. Savella G. Raker CA et al. Preoperative uterine bleeding pattern and risk of endometrial ablation failure. Am J Obstet Gynecol 2014; 211: 556e1-6

5 ）林 保良. 子宮内膜破壞術. 子宮鏡の臨床ABC. 2014 ; 112-123.メジカルビュー社

6 ）林 保良. 三雲美穂. 中田さくら他. 子宮鏡手術の合 併症分析と予後. 産婦人科の実際. 2005; 54(1): 95102.

投稿日：2018年12月17日 採択日：2019年 2 月 25 日 